\title{
Components of litter size in mice after 110 generations of selection
}

\author{
M Holt, O Vangen and W Farstad ${ }^{1}$ \\ Department of Animal and Aquacultural Sciences, Agricultural University of Norway, PO Box 5025, 1432 Ås, \\ Norway and ${ }^{1}$ Department of Production Animal Clinical Sciences, The Norwegian School of Veterinary Science, \\ PO Box 8146 Dep, 0033 Oslo, Norway
}

Correspondence should be addressed to M Holt; Email: marte.holt@iha.nlh.no

\begin{abstract}
The aim of the present study was to evaluate how ovulation rate and survival rate through pregnancy had been affected by more than 110 generations of upwards selection on litter size in mice. The mean number of pups born alive was 22 in the high line (selected line) and 11 in the control line (an increase in 2.6 standard deviations). Selection on litter size increased ovulation rate by 4.6 standard deviations, and it is suggested that selection also increased embryonic mortality in late pregnancy. Embryo survival from ovulation until birth was $66 \%$ in the selected line and $69 \%$ in the control line, and the observed loss in litter size from day 16 of pregnancy until birth was possibly higher in the high line compared with the control line. Selection for higher litter size has significantly increased body weight in both males and females, as the mean weight at mating for the females was $46 \mathrm{~g}$ in the high line and $33 \mathrm{~g}$ in the control line respectively.

Reproduction (2004) 127 587-592
\end{abstract}

\section{Introduction}

Litter size is the result of numerous component traits expressed both in the embryo and in the dam. Ovulation rate sets an upper limit for litter size, but an increase in the number of released ova will not necessarily lead to an increase in litter size. Different factors affecting embryonic mortality have been summarised by Bennett and Leymaster (1989) and include genetic lethal genes, chromosome abnormalities and limited uterus capacity.

The effect of selection for litter size in mice on ovulation rate and embryonic mortality during pregnancy has been reported previously (Joakimsen \& Baker 1977, Bakker et al. 1978, Durrant et al. 1980, Pomp et al. 1988, Clutter et al. 1994, Ribeiro et al. 1996, Johnson et al. 1999). These studies revealed that selection for litter size lead to an increase in ovulation rate, and a subsequent reduction in embryonic mortality. However, few results from long-term experiments have been reported.

Based on the information available from short-term experiments, this study was intended to provide new information on how long-term selection for litter size has affected important components of the trait, such as ovulation rate and embryonic survival.

\section{Materials and Methods}

\section{Animals}

Based on a two-way cross of the outbred strains (L. A. C. Grey and C. F. W.) imported from Britain, three mouse lines were established in the mouse laboratory at the Agricultural University of Norway in 1972 (Joakimsen \& Baker 1977). One line was selected for high litter size, one line was selected for low litter size, and one line was maintained without selection (control). The selection criterion in both the high line and the low line was first parity litter size. Litter size was standardised, when larger than 8 , to 8 pups per litter. The selection method was family selection, with on average two females and two males selected from the top 50 percent of the litters in the selection lines, and random selection in the control line. The selected parents were mated at random, but mating of full sibs, half sibs and cousins was avoided. The lines have undergone different selection strategies over time. Presently, only one high line and the original control line are maintained. The high line has undergone two periods of randomisation and merging of sub lines, including the introduction of a Dutch line in generation 22 (Vangen 1999). The population size varied between 40 and 100 litters/generation during these 110 generations of selection. The control line was maintained 
with the same structure during all generations. This study thus provides data from mice selected on litter size at birth for 110 generations, with a mean litter size in the selected line of 23 and a mean litter size of 12 in the control line (averaged over generations 110-112). For further details on the lines see Joakimsen and Baker (1977) and Vangen (1993 and 1999).

This study comprises mice from generations $110-112$ of the two lines. A total of 55 females and 55 males from the high line and the control line were randomly sampled from each of the three generations. The practised breeding structure in each of the two lines was 40 breeding females per generation, but in order to accommodate this study with no reduction in selection intensities, the number of mice mated was increased to 55 males and 55 females per line in each of these generations (95 breeding females per line in total). Due to the timing of the experiment, mating age differed in the three generations studied. In generation 110, animals were on average 10 weeks old when mated. In generations 111 and 112 they were on average 8.5 and 10.5 weeks old respectively.

The mice were kept in cages of $30 \times 12.5 \times 12.5 \mathrm{~cm}^{3}$ filled at the base with sawdust and had free access to pellet concentrate and water. Lights were on/off for $16 / 8 \mathrm{~h}$, and the ambient temperature was standardised to $23^{\circ} \mathrm{C}$.

\section{Methods}

The male was introduced to the female at the mating ages defined above. Dams from each line were checked for conception by visual inspection for a copulatory plug twice a day. The males were removed from the cage when the copulatory plug was found. Dams that did not show signs of mating after the two weeks mating period were excluded from the experiment. In the high line, $9 \%$ of the animals were excluded; in the control line, $12 \%$ of the animals were excluded. After detection of a copulatory plug, a dam was randomly chosen to be autopsied either 3.5, 8 or 16 days later. The mice were killed by the use of $\mathrm{CO}_{2}$. At day 3.5 each side of the uterus was flushed with $7 \mathrm{ml}$ phosphate buffered saline (PBS), and the number of fertilised and unfertilised ova were counted. At day 8, both the number of implanted embryos and the number of corpora lutea were recorded. At day 16, the number of implantation sites, number of normal fetuses, and the number of corpora lutea were recorded. The number of corpora lutea at days 8 and 16 gave an estimate of the number of ova shed at ovulation. An equal probability of recovering fertilised and unfertilised ova was assumed. Females that were found to be empty or non pregnant at autopsy were not included in the analysis.

In addition to the seven traits described above that were measured directly, records on the number of pups at birth, both alive and stillborn, including number of males and females, were available from the regular recording scheme in each line on all born litters of the contemporary females produced to maintain the lines in each generation.
In generation 112, all females included in the study were weighed at mating. In generations 111 and 112, 50 males from each line had their body weight and testes weight recorded. Measurements were taken after the mating period of 2 weeks. Mean age of the males was 10.5 and 12.5 weeks in generations 111 and 112 respectively. Connective tissue and the epididymis were excluded before the testes were weighed.

\section{Statistical analyses}

The reproductive traits were analysed using a general linear model (SAS 1999). Since recordings over three generations were needed in order to increase the number of observations, a model to test the possible differences between the lines adjusted for generation number, age at mating and a generation* age interaction was fitted. Age at mating and the generation*age interaction had no significant effect on the traits analysed, and were excluded from the model. The model used for the analysis was then:

Reproductive trait $=\mu+$ line + generation number + error (model 1).

For animals with observations on body weight (BW), the following model was fitted:

$\mathrm{BW}=\mu+$ line + generation number + error (model 2 ).

Age was found to be non-significant and was excluded from the model. All the female weights were recorded in generation 112, so the effect of generation on female BW could not be estimated.

Both male and female reproductive traits were adjusted for body weight in order to find any differences between lines after adjusting for body weight. The following model was used:

Reproductive trait $=\mu+$ line $+\mathrm{BW}+$ generation + error (model 3).

Phenotypic correlations between the reproductive traits and body weights were estimated as the correlation between the residuals from model 1 and model 2. Hence, phenotypic correlations between the reproductive traits and body weights after adjusting all traits for the effect of line and generation were estimated.

\section{Results}

\section{Components of litter size}

Table 1 gives the effect of line adjusted for generation number on the different reproductive traits. No significant differences were found between the left and right uterine horn, so the data are presented as a sum of the two sides. Except for the trait number of implanted embryos (day 8), no differences were found between generations. As can be seen from Table 1, the high line had a significantly better performance than the control line for all traits, except number of moles at day 16 of pregnancy. 
Table 1 Number of observations, least square (LS) means for the effect of line adjusted for generation on implanted embryos, corpora lutea, implantation sites, fetuses, moles, litter size, number born alive and percentage of males, and standard errors (S.E.), in the two lines of mice.

\begin{tabular}{|c|c|c|c|c|c|c|}
\hline & \multicolumn{3}{|c|}{ High line } & \multicolumn{3}{|c|}{ Control line } \\
\hline & $n$ & Mean & S.E. & $n$ & Mean & S.E. \\
\hline Implanted embryos (day 8) & 47 & 29.5 & 0.38 & 45 & 14.6 & 0.39 \\
\hline Corpora lutea (days 8 and 16) & 98 & 32.7 & 0.39 & 84 & 16.3 & 0.42 \\
\hline Implantation sites (day 16) & 52 & 29.5 & 0.36 & 41 & 14.4 & 0.41 \\
\hline Normal fetuses (day 16) & 52 & 27.3 & 0.43 & 41 & 13.3 & 0.49 \\
\hline Moles (day 16) & 52 & 0.7 & 0.11 & 41 & 0.2 & 0.12 \\
\hline Litter size (day of birth) & 107 & 22.7 & 0.37 & 104 & 11.5 & 0.38 \\
\hline Number alive (day of birth) & 107 & 21.6 & 0.40 & 104 & 11.3 & 0.41 \\
\hline $\begin{array}{l}\text { Percentage of males (day of } \\
\text { birth) }\end{array}$ & 107 & 46.3 & 1.44 & 104 & 471 & 1.47 \\
\hline
\end{tabular}

The potential litter size in each of the two lines is given by the ovulation rate. The high line mice had a significantly higher mean number of ovulations (Corpora lutea, Table 1), than the control line. When compared with the control line, selection for litter size led to an increase in the ovulation rate of 4.6 standard deviations (pooled) in the high line. During pregnancy, however, the number of potentially viable offspring was reduced in both lines. The mean number of pups born alive in the high line was significantly higher than that of the control line (Number alive, Table 1). For this trait, the increase in the high line versus the control line was 2.6 standard deviations (pooled). When the results from the different groups of animals were compared, the total reduction in litter size from ovulation to birth was found to be $34 \%$ in the high line and $30 \%$ in the control line.

The number of ovulated ova at day 3.5 was found to be $25.5( \pm 5.87)$ in the high line, and 10.9 ( \pm 3.32) in the control line. These numbers are smaller than both the number of corpora lutea and the number of normal fetuses at day 16 in both lines (Table 1). When the results from the different groups of animals are compared, an estimate of the percentage eggs recovered is $78 \%$ in the high line and $67 \%$ in the control line.

Figure 1 presents the losses in litter size throughout pregnancy for mice in the high line and the control line.

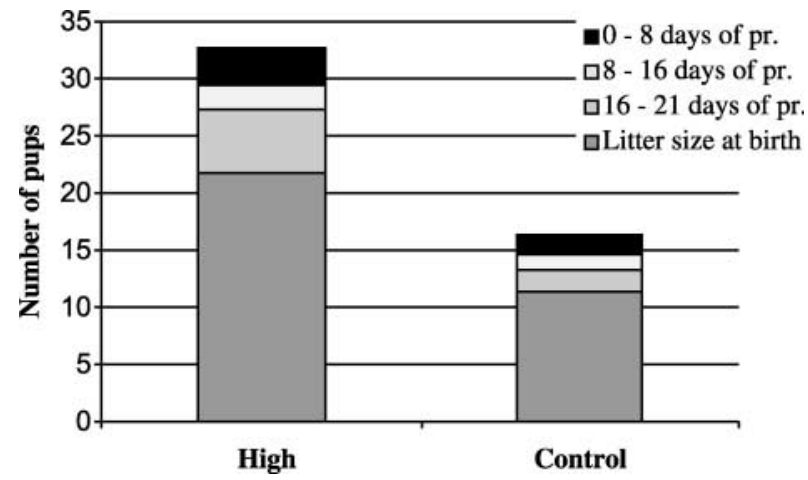

Figure 1 Losses in litter size at different periods of pregnancy (pr.) for mice in the high line and the control line.

The losses are estimated from the least square (LS) means in Table 1, and are thus based on measurements on different animals. From ovulation to birth, the total reduction in litter size was $34 \%$ in the high line and $31 \%$ in the control line. As a percentage of the number of ovulated ova, the losses up to day 8 of pregnancy were about $10 \%$ in both lines. The survival from day 8 to day 16 of pregnancy is no better in the high line than in the control line, but is highly reduced in the high line until day 21 (day of birth). From day 16 to day 21 the losses are $17 \%$ in the high line and $12 \%$ in the control line. The reduction in potential litter size in the high line seems to be highest in the last period of pregnancy (days 16-21) when compared with the two previous periods (days $0-8$ and days 8-16). These differences are not so clear in the control line.

\section{Body weights}

Table 2 presents LS means for the effect of line on male and female body weights adjusted for generation. As seen from the table, selection for litter size has led to a significant increase in body weight for both males and females. For the male body weight, an effect of generation was found on the traits testes weight and body weight.

For females with observations on body weights, a model including body weight as a covariate was analysed to see whether there would still be a difference between the high line and the control line when the traits were adjusted for body weight. The results are given in Table 3.

Table 2 Least square (LS) means (S.E. in parentheses) for the effect of line adjusted for generation on female and male body weights (BW), and empty body weights and testis weights for males in the two lines of mice.

\begin{tabular}{|c|c|c|c|c|}
\hline & \multicolumn{2}{|c|}{ High line } & \multicolumn{2}{|c|}{ Control line } \\
\hline & $n$ & LS mean & $n$ & LS mean \\
\hline \multicolumn{5}{|l|}{ Females } \\
\hline BW (g) & 53 & $46.1^{\mathrm{a}}(0.38)$ & 54 & $33.1^{\mathrm{b}}(0.41)$ \\
\hline \multicolumn{5}{|l|}{ Males } \\
\hline BW (g) & 102 & $50.8^{\mathrm{a}}(0.45)$ & 103 & $44.3^{\mathrm{b}}(0.45)$ \\
\hline Empty BW (g) & 102 & $36.9^{\mathrm{a}}(0.32)$ & 103 & $31.4^{\mathrm{b}}(0.32)$ \\
\hline Testis weight (g) & 102 & $0.39^{\mathrm{a}}(0.004)$ & 103 & $0.30^{\mathrm{b}}(0.004)$ \\
\hline
\end{tabular}

Empty, inner organs removed. Different superscripts indicate significant differences between lines $(P<0.05)$. 
Table 3 Least square means (S.E. in parentheses) for the effect of line adjusted for body weight and generation on implanted embryos, corpora lutea, implantation sites, fetuses, moles and testes weight in the two lines of mice.

\begin{tabular}{lrr}
\hline & High line & Control line \\
\hline Females & & \\
$\quad$ Implanted embryos (day 8) & $26.7^{\mathrm{a}}(1.40)$ & $16.7^{\mathrm{b}}(1.62)$ \\
Corpora lutea (days 8 and 16) & $31.5^{\mathrm{a}}(1.28)$ & $18.0^{\mathrm{b}}(1.46)$ \\
Implantation sites (day 16) & $28.9^{\mathrm{a}}(0.77)$ & $15.1^{\mathrm{b}}(0.87)$ \\
$\quad$ Normal fetuses (day 16) & $26.9^{\mathrm{a}}(1.10)$ & $14.0^{\mathrm{b}}(1.24)$ \\
Moles (day 16) & $0.8^{\mathrm{a}}(0.46)$ & $0.1^{\mathrm{a}}(0.52)$ \\
Males & $0.38^{\mathrm{a}}(0.005)$ & $0.31^{\mathrm{b}}(0.005)$ \\
$\quad$ Testes weight &
\end{tabular}

Different superscripts indicate differences between lines $(P<0.05)$.

After adjusting for body weight at mating, the high line still had a better performance than the control line for all traits, but the differences between the lines were smaller than the differences presented in Table 1.

For the testes weights, LS means for the effects of line adjusted for both generation and body weight were estimated. The results are given in Table 3. After adjusting for body weight, the testes weight in the high line was still significantly higher than the testes weight in the control line.

No significant correlations between body weight and the female reproductive traits were found (Table 4 ), but in males a positive correlation of $0.27(P<0.0001)$ between body weight and testes weight was estimated.

\section{Discussion}

Joakimsen and Baker (1977) described changes in litter size and ovulation rate as a result of selection for litter size in the early generations of the selection experiment. After 15 generations of selection, they reported an increase of $44 \%$ for the trait litter size in the high line compared with the control line. It was concluded that this increase was due to an increased ovulation rate $(40 \%)$. After an additional 95 generations with continued selection for high litter size at first parity, the high line now has a mean litter size of 22 pups, which is an increase of $90 \%$

Table 4 Phenotypic correlations for number of implanted embryos, corpora lutea, implantation sites, fetuses and moles to body weight in female mice, and between testes weight and body weight in male mice, all traits adjusted for line and generation.

\begin{tabular}{lcr}
\hline Traits & $\begin{array}{c}\text { Correlation to } \\
\text { body weight }\end{array}$ & P-value \\
\hline Females & & \\
$\quad$ Implanted embryos (day 8) & 0.27 & 0.1990 \\
$\quad$ Corpora lutea (days 8 and 16) & 0.18 & 0.1896 \\
Implantation sites (day 16) & 0.21 & 0.2643 \\
$\quad$ Normal fetuses (day 16) & 0.18 & 0.3399 \\
$\quad$ Moles (day 16) & -0.56 & 0.1506 \\
Males & & \\
$\quad$ Testes & 0.27 & $<0.0001$ \\
\hline
\end{tabular}

Reproduction (2004) 127 587-592 compared with the control line. The increase in litter size in the present study was also found to be due to an increase in the ovulation rate.

The number of ova at day 3.5 was found to be much smaller than both the number of corpora lutea and the number of normal fetuses at day 16. Although these numbers are based on measurements in different animals, we can conclude that not all ova have been detected by flushing the uterus at day 3.5. When the study was designed, an equal probability of recovering fertilised and unfertilised ova was assumed. However, it has been reported for a variety of animal species that the rate of transport of fertilised and unfertilised ova in the oviduct differs e.g. in the horse (Betteridge \& Mitchell 1974), hamster (Ortiz et al. 1986) and rat (Viggiano et al. 1992), whereas in pigs no such difference has been demonstrated (Mwanza et al. 2002). It is possible that retention of unfertilised ova, which thus escaped observation, may be the reason for the discrepancy between the recovery rate at 3.5 days post mating and the number of corpora lutea and embryos at day 16.

After 15 generations of selection, Joakimsen and Baker (1977) reported an increase in fertilisation rate of $7 \%$ compared with the control line, and a reduction of $5 \%$ in the implantation rate. No effect of selection for litter size on fertilisation rate and early embryonic survival could be found is this study. Bakker et al. (1978) and Durrant et al. (1980) reported a reduction in embryonic mortality at earlier stages of pregnancy, as a result of selection for high litter size. The reason why no, or only a small effect, of selection for litter size on early embryonic mortality could be found in the present study may be because embryonic mortality is not directly affected by limitations in the maternal environment (Knight et al. 1977). Mortality during this first phase is also supposed to be independent of the influence from other ova/embryo (Bennett \& Leymaster 1989).

In later stages of pregnancy, embryo survival is affected by the uterine capacity of the dam (Bennett \& Leymaster 1989). In our study, a reduction in litter size of $18 \%$ from day 16 of pregnancy until the day of birth was found in the high line. In the control line, the litter size was reduced by $12 \%$ in the same period. Because of the increase in mortality during the last period of pregnancy, the embryo mortality is possibly higher in the high line than in the control line. A negative phenotypic correlation between ovulation rate and prenatal survival has been reported by several authors (reviewed by Blasco et al. 1993), but the opposite results have also been published. Joakimsen and Baker (1977), Bakker et al. (1978) and Durrant et al. (1980) all reported reduced embryo mortality during pregnancy as a result of selection for high litter size. The possibly increased embryonic mortality found in this study raises the question as to whether the increased late pregnancy mortality found in our study is caused by a limited uterus capacity. Also, the individual influence of litter size on pup mortality per female should be studied, to see if it is a consistent co-variation between 
those parameters. Birth weights have not been registered in this study, but differences in birth weights could be one factor influencing survival in late pregnancy.

Clutter et al. (1994) and Wiebold and Becker (1987) reported differences in the number of fetuses between the right and left side of the reproductive tract. The right reproductive tract was found to contain more fetuses than the left horn. No differences between right and left uterine horns were found for any of the traits in the present study. The duplex nature of the mouse uterus does not exist in multiparous livestock species, such as the pig. In pregnant rats differences in blood flow to the right and left uterine horn have been demonstrated. This significantly affected local placental development and may consequently affect fetal survival, i.e. favouring fetal survival in the right uterine horn (Even et al. 1994). Since there are species differences with respect to this phenomenon, more studies are needed to evaluate possible interactions between left and right uterine horns in the mouse.

Selection for larger litter size has led to an increase in female body weight (Joakimsen \& Baker 1977, Durrant et al. 1980, Fuente et al. 1986, van Engelen et al. 1995) with some exceptions (Bakker et al., 1978). An increased body weight was also found for the females in the high line in this study. Other studies from this long-term experiment have shown that weights at both 3 and 6 weeks are highly changed as a result of selection for litter size (Vangen 1999, Holt 2001, Rauw 2001). Both the present study and an additional study along the same lines published by Rauw et al. (2003) reveal that the high line females produce more offspring relative to their own body weight. According to Rauw et al. (2003), the high line females also produce more offspring at a greater cost to their own metabolism, which results in reduced pup development and increased preweaning mortality rates.

Selection for litter size has also led to an increase in the male body weight and testes weight. Rauw et al. (2000) analysed mature body weight and maturation rate in the selected line and the control line. They found that mice selected for high litter size in addition to a higher mature body weight also had a higher scaled maturation rate (maturation rate adjusted for mature size) than the control line.

Although selection for litter size has been very successful in animal laboratories, one cannot expect the same response to be obtained for other animals in a production environment. In general, there are many causes for the lack of response when selecting for fertility: natural selection working against fertility selection, genotype and environment interactions, small additive genetic variance, genetic and environmental maternal effects. Also, traits other than fertility traits are often included in the breeding objectives, and these may have unfavourable genetic correlations with fertility traits. However, as stated by Eisen (1998): 'The laboratory animal model is positioned to make crucial contributions to our understanding of the dynamics of selection and to complement selection experiments with economic species'.

\section{Acknowledgements}

The authors are grateful to S Pal and C Zhang for their technical assistance. The study was supported by the Norwegian Research Council through a PhD and project grant.

\section{References}

Bakker HJ, Wallinga JH \& Politiek RD 1978 Reproduction and bodyweight of mice after long-term selection for large litter-size. Journal of Animal Science 46 1572-1580.

Bennett GL \& Leymaster KA 1989 Integration of ovulation rate, potential embryonic viability and uterine capacity into a model of litter size in swine. Journal of Animal Science 67 1230-1241.

Betteridge K \& Mitchell D 1974 Direct evidence of retention of unfertilised ova in the oviduct of the mare. Journal of Reproduction and Fertility 39 145-148.

Blasko A, Bidanel JP, Bolet G, Haley CS \& Santacreu MA 1993 The genetics of prenatal survival of pigs and rabbits: a review. Livestock Production Science 37 1-21.

Clutter AC, Kochera Kirby YL \& Nielsen MK 1994 Uterine capacity and ovulation rate in mice selected 21 generations on alternative criteria to increase litter size. Journal of Animal Science $\mathbf{7 2}$ $577-583$.

Durrant BS, Eisen EJ \& Ulberg LC 1980 Ovulation rate, embryo survival and ovarian sensitivity to gonadotrophins in mice selected for litter size and body weight. Journal of Reproduction and Fertility 59 329-339.

Eisen EJ 1998 Selection theory and experiments. Chairman's summary. Proceedings of the 6th Congress on Genetics Applied to Livestock Production Armidale, Australia 26 67-68.

van Engelen MAJ, Nielsen MK \& Ribeiro El de A 1995 Differences in pup weight, pup variability within litters, and dam weight of mice selected for alternative criteria to increase litter size. Journal of Animal Science 73 1948-1953.

Even MD, Laughlin MH, Krause GF \& vom Saal FS 1994 Differences in blood flow to uterine segments and placentae in relation to sex, intrauterine location and side in pregnant rats. Journal of Reproduction and Fertility 102 245-252.

Fuente LF, San-Primitivo F \& Bayon Y 1986 Genetic correlation between litter size and body weight in mice. Zeitschrift-für-Tierzuechtung-und-Zuechtungsbiologie 103 249-254.

Holt M 2001 Selection for litter size in mice; correlated responses in body weight. Masters thesis, Department of Animal Science, Agricultural University of Norway.

Joakimsen Ø \& Baker RL 1977 Selection for litter size in mice. Acta Agriculturae Scandinavica 7 301-318.

Johnson RK, Nielsen MK \& Casey DS 1999 Responses in ovulation rate, embryonal survival and litter traits in swine to 14 generations of selection to increase litter size. Journal of Animal Science 77 $541-557$.

Knight JW, Bazer FW, Thatcher WW, Franke DE \& Wallace HD 1977 Conceptus development in intact and unilaterally hysterectomized-ovariectomized gilts: interrelations among hormonal status, placental development, fetal fluids and fetal growth. Journal of Animal Science 44 620-637.

Mwanza M, Razdan P, Hulten F \& Einarsson S 2002 Transport of fertilized and unfertilized ova in sows. Animal Reproduction Science 74 69-74.

Ortiz ME, Bedregal P, Carvajal MI \& Croxatto HB 1986 Fertilized and unfertilized ova are transported at different rates by the hamster oviduct. Biology of Reproduction 34 777-781. 
Pomp D, Eisen EJ \& Ziecik AJ 1988 LH receptor induction and ovulation rate in mice selected for litter size and body weight. Journal of Reproduction and Fertility 84 601-610.

Ribeiro EL de A, van Engelen MAJ \& Nielsen MK 1996 Embryonal survival to 6 days in mice selected on different criteria for litter size. Journal of Animal Science 74 610-615.

Rauw WM 2001 Changes in food resource allocation patterns with selection for litter size: a mouse model. ISBN 82-7479-011-011. Doctor of Agriculture thesis, Agricultural University of Norway, PO Box 5025 N-1432Ås, Norway.

Rauw WM, Luiting MWA, Verstegen $O$, Vangen $O$ \& Knap PW 2000 Differences in food resource allocation in a long-term selection experiment for litter size in mice. I. Developmental trends in body weight and food intake against time. Animal Science $\mathbf{7 1}$ 31-38.

Rauw WM, Knap PW, Gomez-Raya L, Varona L \& Noguera JL 2003 Reallocation of body resources in lactating mice highly selected for litter size. Journal of Animal Science 81 939-944.

SAS 1999 SAS users guide: statistics. Version 8. Cary NC, USA: Sas Institute Inc.
Vangen O 1993 Results from 40 generations of divergent selection for litter size in mice. Livestock Production Science 37 $197-211$.

Vangen O 1999 Long term selection for litter size in mice (>100 generations); correlated responses and biological constraints. 50th Annual Meeting of the European Association for Animal Production. Zürich, Switzerland.

Viggiano M, Cebral E, Gimeno AL \& Gimeno MA 1992 Probable influence of ova and embryo prostaglandins in the differential ovum transport in pregnant and cycling rats. Prostaglandins, Leukotrienes and Essential Fatty Acids 45 211-215.

Wiebold JL \& Becker WC 1987 Inequality in function of the right and left ovaries and uterus horns of the mouse. Journal of Reproduction and Fertility 79 125-134.

Received 25 November 2003

First decision 27 January 2004

Accepted 3 March 2004 